\title{
1966: A Year of Continued Expansion in the Central Mississippi Valley
}

E 1 CONOMIC ACTIVITY in the Central Mississippi Valley advanced at a brisk pace during 1966 , with regional gains roughly paralleling those in the nation. Population increased only slightly, but employment and personal income in Arkansas, Kentucky, Mississippi, Missouri, and Tennessee combined were well above year-earlier levels. In the metropolitan areas of the region (Eighth Federal Reserve District), employment, spending, and banking activity moved strongly upward, with largest increases occurring in the first half of the year.

Population in the Central Mississippi Valley rose an estimated 0.6 per cent during the year ending in mid1966 compared with a 1.1 per cent annual rate from 1960 to 1965 (Table I). In the nation population growth also slowed last year, declining to a 1.1 per cent rate from a 1.6 per cent average rate during the previous five years.

NOTE: Data for the Central Mississippi Valley and for each state and metropolitan area discussed in this article are published monthly in a release, "Selected Economic Indicators-Central Mississippi Valley," which is available upon request.
Total employment in the Central Mississippi Valley advanced 1.1 per cent during the past year, with the long-term decline in agricultural employment continuing to partially offset gains in other industries. Payroll employment, which excludes agricultural, unpaid family, domestic, and self-employed workers, increased 4.4 per cent, about equal to the national rate of expansion. Manufacturing employment rose sharply and by late 1966 was 6 per cent above year-earlier levels. Increased production by ordnance plants in several areas contributed to this gain. Nonmanufacturing employment increases were slightly above the average rate of the preceding five years.

Total personal income in the Central Mississippi Valley advanced at about the same rate as the 8 per cent national gain from 1965 to 1966 despite the slower rate of population growth in the region. Per capita personal income rose 8 per cent in the Valley, somewhat more than the 7 per cent gain nationally. Per capita income in the five states of the Valley averaged about $\$ 2,285$ in 1966 , with income in each of the states below the estimated national average of $\$ 2,985$,

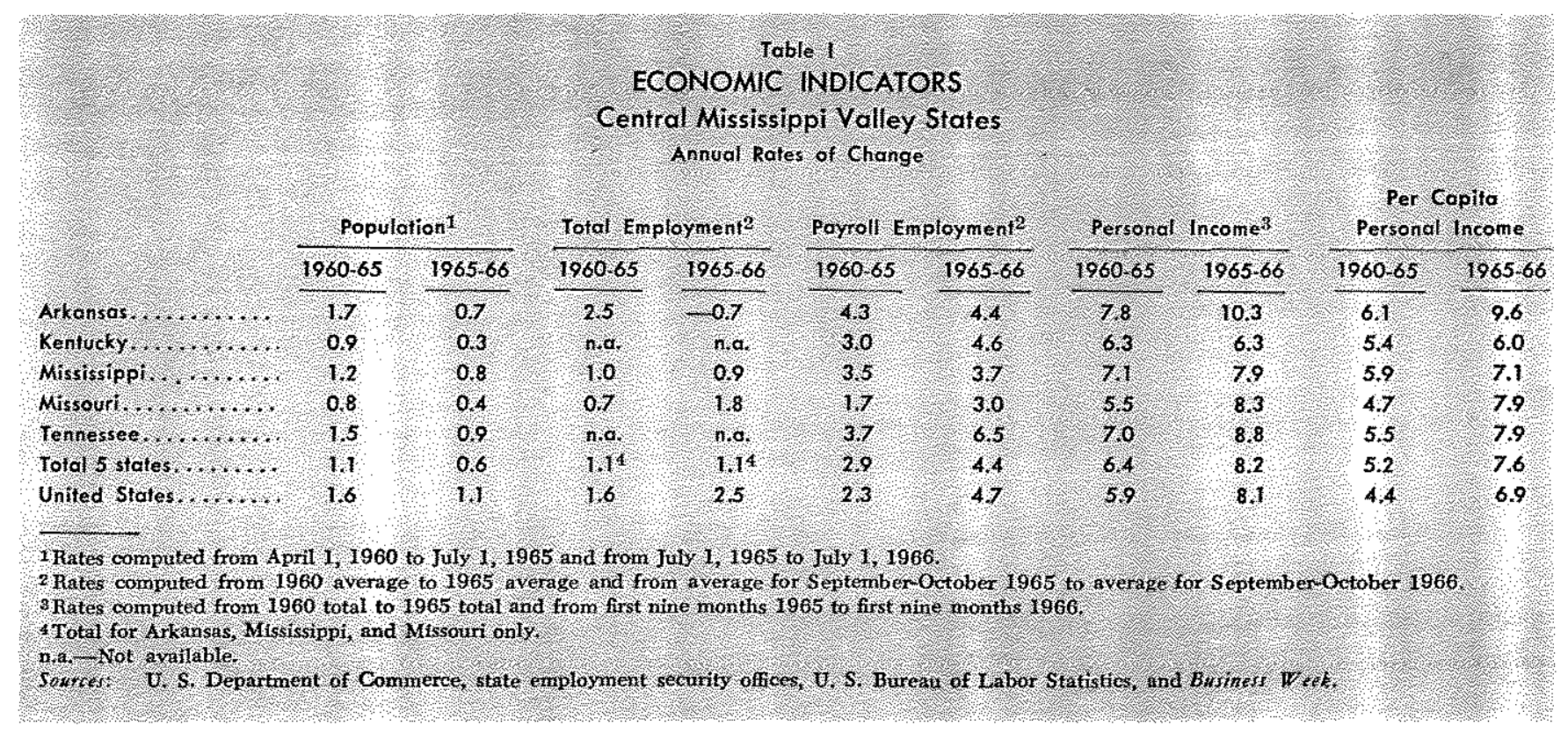

Page 5 
In the metropolitan areas of the region spending and banking activity increased substantially from late 1965 to late 1966, but the rates of increase were somewhat less than in the nation. Check payments, often used as an indicator of spending, rose sharply in the region during the first six months and subsequently remained about unchanged. The net increase was 10 per cent compared with a national gain of 12 per cent and with a regional growth rate of 9 per cent in the preceding five years (Table II), Business loans at weekly reporting banks of the region in late 1966 were 10 per cent above year-earlier levels compared with an 18 per cent gain for the nation; bank deposits rose rapid. ly to midyear and then leveled off, corresponding to the national pattern.

Since growth rates varied greatly among the states and metropolitan areas, each state and area is discussed separately in this article. The primary period considered is late 1965 to late 1966. The average growth rate from 1960 to 1965 is used to place recent developments in perspective.

\section{Arkansas}

Economic activity in Arkansas continued to expand at a rapid rate during 1966 , as indicated by significant gains in payroll employment, particularly in manufacturing employment, and in personal income. Population continued to rise but at a reduced rate. Estimated population in Arkansas in mid-1966 was $1,955,000$, a 0.7 per cent gain from mid-1965. In the preceding five years population advanced at a 1.7 per cent annual rate, slightly above the 1.6 per cent rate for the United States as a whole.

Total employment in the fall of 1966 was slightly below the year-earlier level, reflecting a substantial decline in farm employment. The unemployment rate declined to 4.3 per cent of the labor force in late 1965 and remained about unchanged at this relatively low rate through 1966.

Nonfarm payroll employment rose rapidly from Fate 1965 through April and then remained about unchanged. Manufacturing employment rose rapidly from late 1965 to January 1966, remained about unchanged through June, and increased again in the last half of the year. For the year as a whole, such employment increased 7 per cent, with the machinery, food, lumber and wood products, and furniture industries each employing at least 1,000 more workers than in late 1965. Nonmanufacturing employment grew rapidly in the early months of the year but remained about unchanged during the remaining months.

Total personal income in Arkansas advanced 10 per cent from 1965 to 1966, the highest rate for any Valley state. Per capita income rose from $\$ 1,845$ to $\$ 2,022$, a gain of 10 per cent. Although per capita personal income has grown rapidly in Arkansas in most recent years, it is still well below both the regional and national averages.



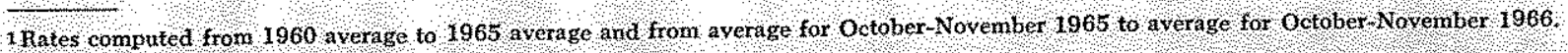

Three-nonth novine averag.

selected sannle of banks.

Denand deposits onily

trow lons.

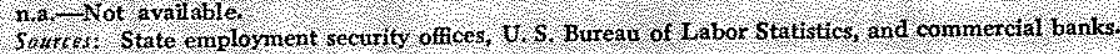




\section{Little Rock ${ }^{1}$}

Economic activity in the Little Rock area grew moderately in 1966, but some indicators showed little or no gain in the later months of the year. Employ. ment, spending, and banking activity all advanced less rapidly than in previous years.

Total employment rose less than 1 per cent during the year, well below the longer term growth rate. The labor force, however, was fully utilized and remained about unchanged from late-1965 levels. Unemployment averaged only 2.4 per cent of the labor force during the 12 months ending in November 1966, the lowest for any metropolitan area of the region.

Payroll employment rose 2.0 per cent during the year, with manufacturing gains exceeding those in nonmanufacturing until strikes caused a sharp drop in apparel and nonelectrical machinery manufacturing in November. Metal working was the fastest growing manufacturing industry. In the nonmanufacturing category government employment increased substantially, while contract construction employment declined.

Check payments rose 8 per cent from late 1965 to late 1966 , with practically all the growth concentrated in the early part of the period. This indicator of spending declined sharply in November 1966, probably reflecting the decline in employment because of strikes.

Banking activity rose rapidly from late 1965 to April 1966 and then leveled off. Deposits moved up 7 per cent for the year as a whole, while business loans expanded 12 per cent. The increase in deposits was slightly below the trend rate, while the increase in business loans was somewhat above the average 11 per cent rate of gain from 1960 to 1965 .

\section{Fort Smith ${ }^{2}$}

The Fort Smith economy, which was seriously affected by the closing of Fort Chaffee in 1965, continued to decline during 1966. Employment rose early in the year, but the increase was more than offset by a decline during the second half. Check payments rose moderately, and other banking activity remained about unchanged.

Total employment declined 3.5 per cent during the year ending in the fall of 1966 , while the labor force

\footnotetext{
1 The Standard Metropolitan Statistical Area (SMSA) is Pulaski County, Arkansas.

2The SMSA consists of Sebastian and Crawford Counties, Arkansas and LeFlore and Sequoyah Counties, Oklahoma.
}

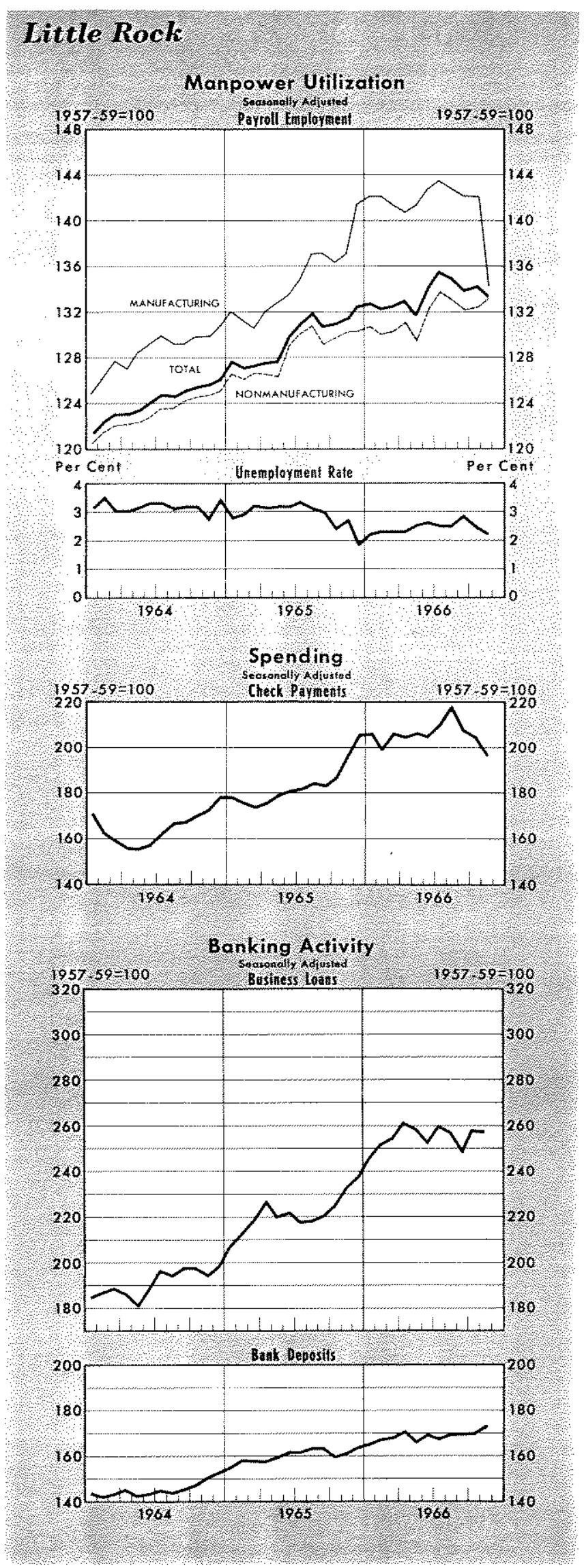

Page 7 


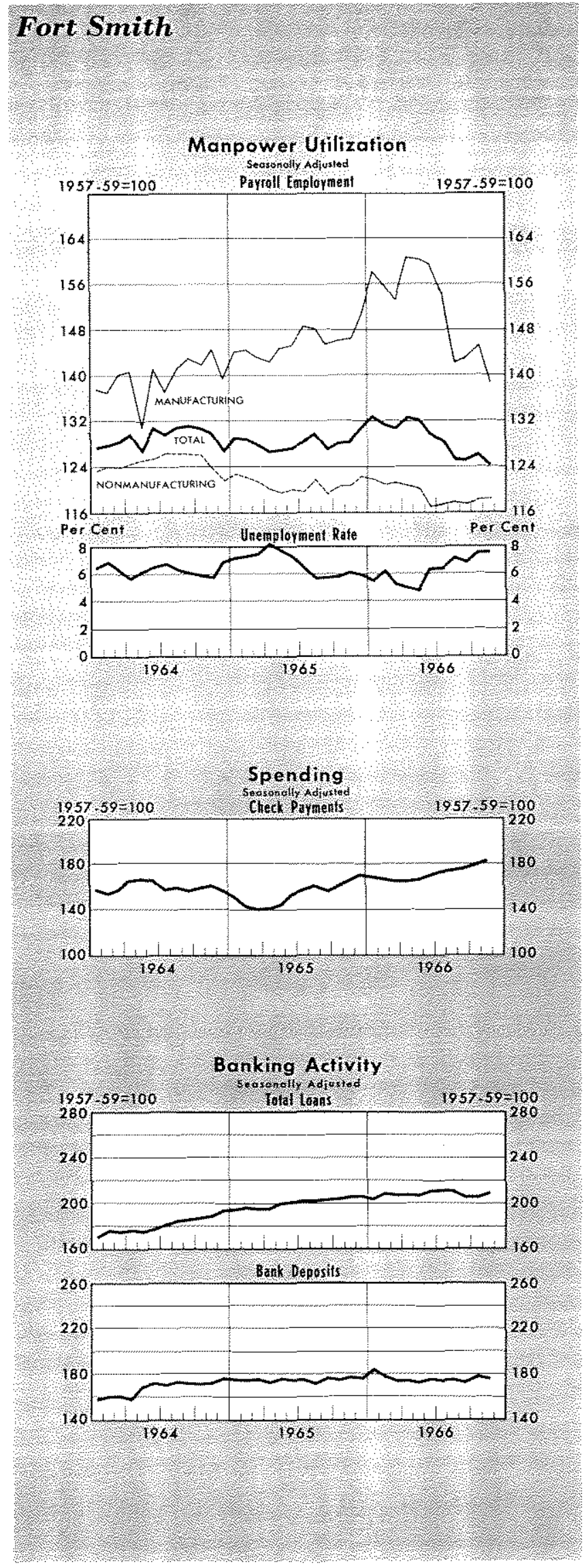

increased slightly. Consequently, the unemployment rate rose markedly, from 6.0 per cent of the labor force in the autumn of 1965 to 7.6 per cent a year later. Unemployment has generally been between 6 and 7 per cent of the labor force during the past three years. Fort Smith was the only metropolitan area in the Central Mississippi Valley classified as an "area of substantial unemployment" in 1966.

Payroll employment in the area declined 2.4 per cent from late 1965 to late 1966 , in contrast to a 6 per cent average annual rate of growth during the period 1960-65. Manufacturing employment was 3.0 per cent below year-earlier levels. Employment in the metals industry dropped sharply while one plant retooled following a change in ownership, but employment in the food processing and furniture industries increased. Strikes in the stone, clay, and glass industry and in the metals industry late in the year contributed to the depressed level of manufacturing employment. Nonmanufacturing employment continued to decline from the high level reached in mid1964, with employment in contract construction showing the sharpest decline.

Check payments in Fort Smith were counter to the general trend of economic activity, expanding 10 per cent in 1966, slightly above the 8 per cent average rate of expansion from 1960 to 1965.

Banking activity, which had risen rapidly since the late $1950^{\circ} \mathrm{s}$, continued to increase but at a reduced rate. Deposits rose only 0.9 per cent, and total loans, 1.2 per cent compared with growth rates of 11 and 12 per cent, respectively, from 1960 to 1965.

\section{Pine Bluff}

Economic activity in the Pine Bluff area declined somewhat last year following a period of rapid growth from 1960 to 1965. Employment and banking activity were only slightly below year-earlier levels, but spending, as measured by check payments, dropped sharply during the second half of the year.

Total employment decreased 0.9 per cent, primarily because a small cotton crop reduced the demand for agricultural workers. The unemployment rate rose slightly, from 3.6 to 3.8 per cent. Payroll employment, which had increased rapidly in late 1965 , reached a high level in January and then declined somewhat.

Check payments rose rapidly until July and then declined sharply through October and November, reflecting the general decline in other sectors of the economy.

${ }^{3}$ The SMSA is Jefferson County, Arkansas. 
Banking activity also slowed last year. After rising in the first three quarters of the year, total loans declined markedly in October. Bank deposits changed little on balance during the year in contrast to a 9 per cent annual growth rate in the preceding five years.

\section{Kentucky}

The year 1966 was one of moderate economic growth in Kentucky, following very rapid growth in 1965. During the past year population, employment, and income all expanded somewhat less rapidly than in the previous year.

The population of the state was estimated at $3,183,000$ in mid-1966, up 0.3 per cent from 1965 . Since 1960 population has increased at a 0.9 per cent average annual rate, about half the average rate of 1.6 per cent for the nation.

Payroll employment rose 4.6 per cent during the year ending in late 1966, with most of the gain occurring prior to April. Manufacturing employment increased somewhat more rapidly than nonmanufacturing, with sizable gains in the petroleum refining and rubber products and electrical and nonelectrical machinery industries. In the nonmanufacturing sector government and trade had much higher levels of employment than a year earlier. Partially offsetting these gains was a sharp decline in contract construction employment, reflecting the housing slump.

Personal income rose 6.3 per cent from 1965 to 1966 , a slightly lower rate than the average for the Valley but equal to the average rate of gain for Kentucky from 1960 to 1965 . The growth of personal income in the state during these five years more than kept pace with the 5.9 per cent rate of growth in the nation but was slightly below the 6.4 per cent average rate for the Valley. Per capita personal income in Kentucky in 1966 was estimated at $\$ 2,168$, about average for the Valley but well below the estimated $\$ 2,935$ average in the nation.

\section{Louisville $^{*}$}

Economic activity in the Louisville metropolitan area rose significantly during 1966. Employment, spending, and banking activity increased at rates well above the trend rate.

Total employment expanded 4.7 per cent, more than double the 1.8 per cent average rate for the previous five years. The unemployment rate remained about 3 per cent throughout the year, generally below the rate

4he SMSA consists of Jefferson County, Kentucky and Clark and Floyd Counties, Indiana.

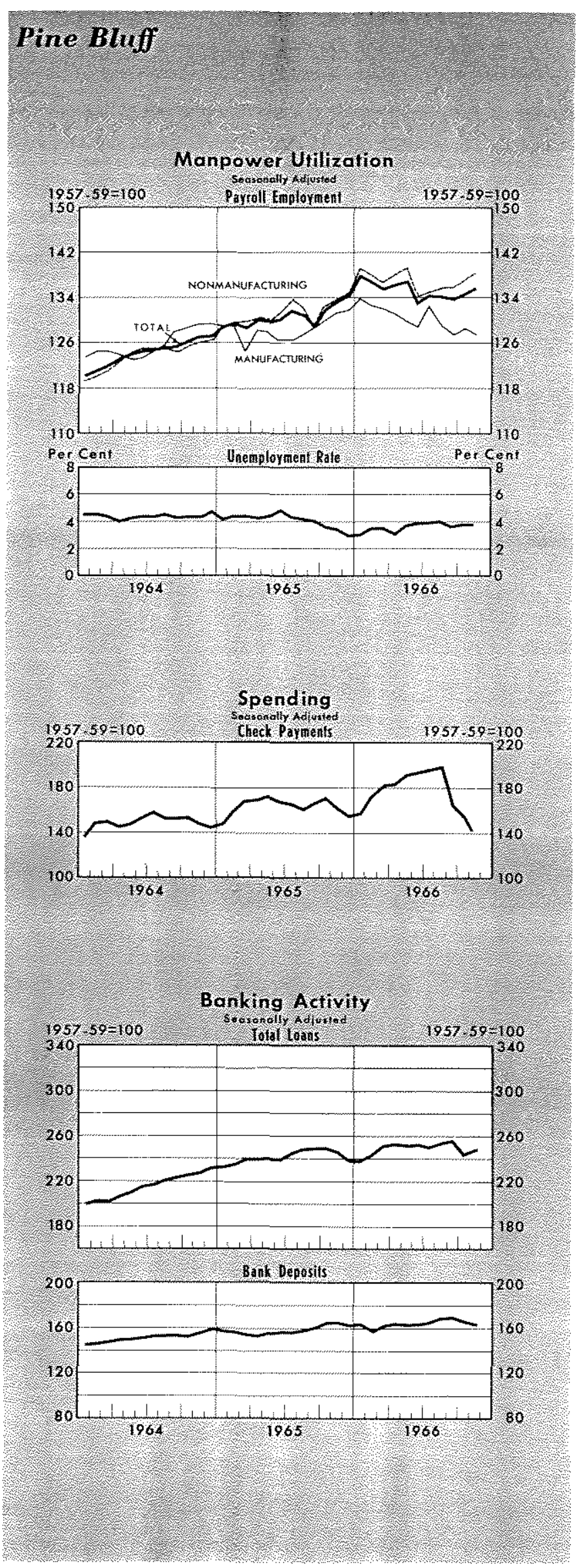

Page 9 


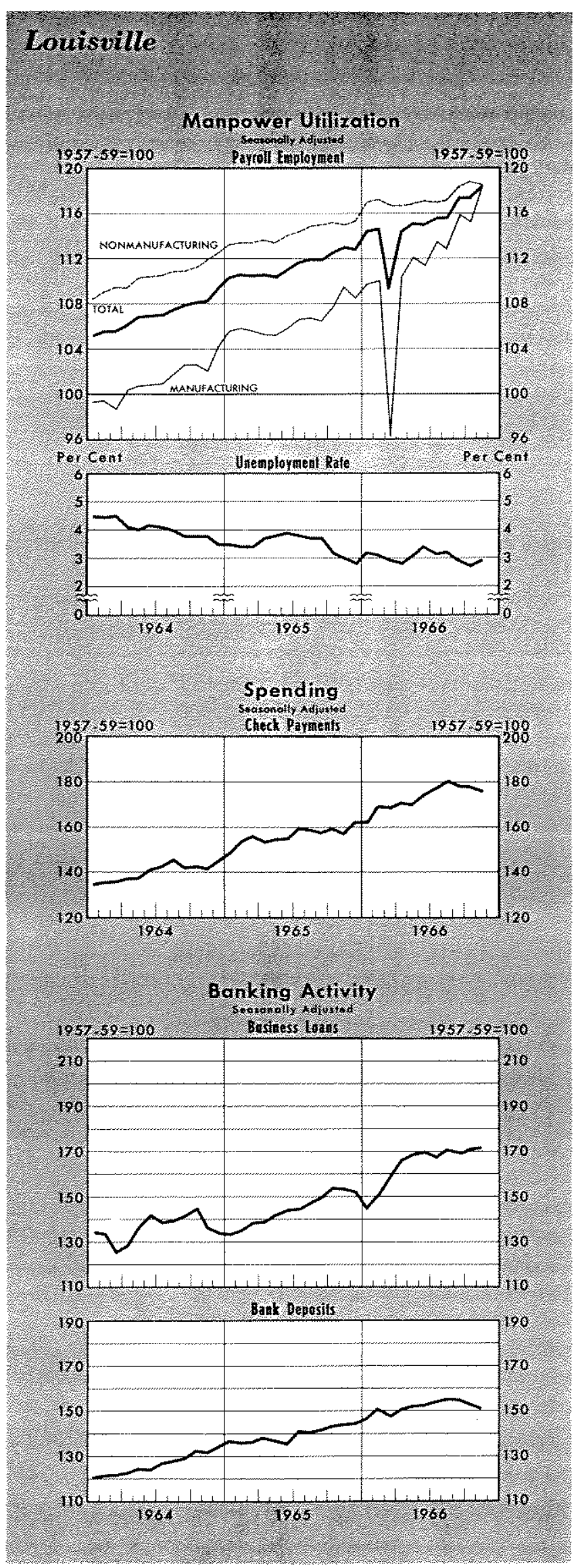

of the preceding year and well below the 1960-65 average.

Payroll employment advanced 4.6 per cent, with manufacturing employment expanding more than twice as fast as nonmanufacturing employment. Increased production of machinery and of war materials was primarily responsible for the gain in manufacturing employment. Labor disputes tended to retard business activity. In March several thousand workers in the electrical appliance industry were on strike, and manufacturing employment levels dropped sharply. In each month from June to October at least 1,000 workers were on strike during each employment-reporting period.

Spending in Louisville, as measured by check payments, rose quite rapidly during most of the year. A 12 per cent net gain for the 12 -month period ending in November was only slightly less than the national growth rate.

Banking activity advanced during the 12 months ending in November 1966 at a rate slightly greater than the trend rate. Deposits rose 5 per cent, somewhat less than the 7 per cent rate of the preceding five years. Business loans expanded 12 per cent, primarily in the early part of the year; the longer run rate of expansion was 6 per cent.

\section{Evansville, Indiana-Kentucky ${ }^{5}$}

The economy of the Evansville area, which showed little net gain during 1965, moved up strongly in 1966. Manufacturing employment and bank deposits increased substantially.

Total employment expanded 6 per cent compared with a 2.4 per cent average rate from 1960 to 1965 . The unemployment rate, 2.9 per cent of the labor force in late 1966, was about unchanged from a year earlier.

Payroll employment in Evansville rose at a faster pace than in the nation, reflecting primarily a 15 per cent increase in the manufacturing sector. Employment in the refrigeration and air-conditioning equipment industry rose by more than 2,000 workers. In addition, a new industrial operation in the area began hiring personnel to work on defense contracts. This plant is expected to expand during 1967. A small gain in nonmanufacturing employment was concentrated in the government category.

Check payments in Evansville rose 6 per cent during the 12 months ending in November, well below

5 The SMSA consists of Vanderburgh and Warrick Counties, Indiana and Henderson County, Kentucky. 
the 8 per cent trend rate of the preceding five years. Other banking trends were mixed. Deposits expanded very rapidly, while business loans showed only a slight increase. This experience was the reverse of the national pattern. Total deposits expanded 12 per cent, and business loans, 3.1 per cent. In contrast, deposits nationally expanded 3.5 per cent, and loans, 18 per cent. This diversity of trends in Evansville compared with the nation may reflect the source of capital involved in the area's expansion. Most of the employment growth in Evansville was in plants owned by larger national corporations which borrowed elsewhere for local expansion. The area's bank deposits, however, reflected new income and savings generated by the expansion.

\section{Mississippi}

Economic activity in Mississippi advanced at about the same rate in 1966 as in the $1960-65$ period.

Population rose 0.8 per cent from mid-1965 to mid1966 compared with a 1.2 per cent average rate of growth in the previous five years. Population in the nation increased 1.I per cent during the year.

Total employment in the state rose 0.9 per cent during the past year, slightly below the average 196065 growth rate. Agricultural employment rose less than seasonally during the fall months as bad weather and a smaller cotton crop reduced the demand for farm workers.

Payroll employment advanced 3.7 per cent over levels of late 1965, with manufacturing employment gains slightly more rapid than nommanufacturing gains. Among durables the furniture, primary metals, and electrical machinery industries showed the largest increases in number of workers. In the nondurable goods category employment in the apparel industry rose substantially. Government employment in most recent months was well above year-earlier levels, and several other nonmanufacturing categories showed small increases.

Personal income in the state expanded about 8 per cent last year. This increase was about the same as for the nation as a whole. Estimated per capita personal income of $\$ 1,722$ was 7 per cent greater than in 1965 , about the same gain as nationally.

\section{Missouri}

Economic trends in Missouri were mixed in 1966. Employment gains were striking compared with those of previous years, though population expanded less rapidly than the average $1960-65$ rate. Personal in-

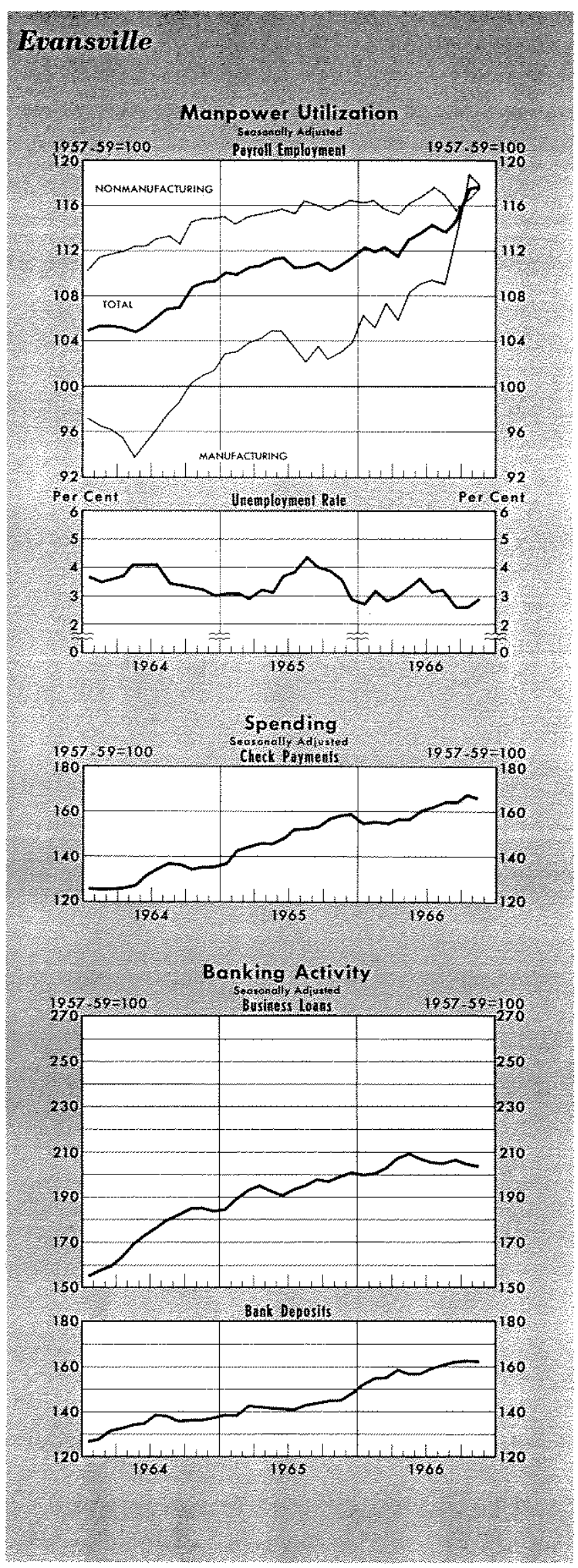

Page 11 




come also rose at a higher rate than in the longer run period.

Population was estimated at 4,508,000 in mid-1966, a 0.4 per cent gain from a year earlier. In the five years 1960-65 population rose at an 0.8 per cent average rate, half the rate for the United States as a whole.

Total employment increased 1.8 per cent during the past year, substantially above the 0.7 per cent average rate of growth from 1960 to 1965 . Unemployment was about 3.1 per cent of the labor force in 1966, a little below the level of a year earlier.

Payroll employment advanced more rapidly during 1966 than in any year since the late 1950 's. The 3.0 per cent rate of gain was almost double the 1.7 per cent average annual rate for the longer run period. Manufacturing employment rose 4.7 per cent, with all major durables industries, particularly ordnance and transportation equipment, showing increases. Much of the 2.3 per cent rise in nonmanufacturing employment was attributable to an increase in government workers.

Personal income in Missouri rose 8 per cent during the year, about the same rate as in the nation and greater than the trend rate in Missouri. Per capita personal income, estimated at $\$ 2,873$, was higher than in any of the other Central Mississippi Valley States and 8 per cent above the year-ago level for Missouri.

\section{St. Louis $^{6}$}

The St. Louis economy advanced rapidly during the first half of 1966 but leveled off somewhat after midyear. Net growth for the year was well above trend rates for St. Louis but below the national average.

Total employment in the area rose 3.I per cent, about triple the 1960-65 average rate of gain. Employment gains during the past year would probably have been even greater had there not been an increase of labor disputes. In only three of the first ten months did striking workers number under 1,000 , and, at one time in the last half of $1966,7,000$ workers were on strike. Unemployment declined to 3.2 per cent of the labor force in the autumn compared with 3.4 per cent a year earlier.

Payroll employment rose rapidly through June and then stabilized, with the level during the fall 4.2 per cent above a year earlier. The annual rate of gain in the previous five years was 1.6 per cent. In the long-

GThe SMSA consists of St. Louis City, St. Louis, St. Charles, Jefferson, and Franklin Counties, Missotri and Madison and St. Clair Counties, Illinois. 
run period, manufacturing employment showed only a slight increase, as gains in durable goods employment were largely offset by declines in nondurables. In the early part of the past year, however, manufacturing employment rose sharply and stabilized at a high level after March. Employment increased during the year in the production of both durable and nondurable goods. Employment in the transportation equipment industry continued to expand more rapidly than in any other area of manufacturing. The manufacture of aircraft and parts employed several thousand more workers than in 1965. The ordnance industry will probably grow rapidly as a new defense plant is staffed. Nonmanufacturing employment expanded 4.6 per cent, with most of the expansion in the first half of the year. The trade, service, and govemment fields each employed about 7,000 more workers in late 1966 than a year earlier.

Total spending, as measured by check payments, rose rapidly from late 1965 to mid-1960 and leveled off during the last half of the year. The net gain for the year was 12 per cent compared with a 10 per cent average rate from 1960 to 1965 .

Banking trends were mixed. Deposits at weekly reporting banks rose in the first half of the year but were about unchanged after June. Deposit expansion for the whole year was only 2.7 per cent, compared with a 6 per cent trend rate and a 3.5 per cent increase in the United States last year. Business loans rose 18 per cent, with all of the increase in the first half of the year.

\section{Springfield}

Economic activity in the Springfield area was marked by rapid growth in manufacturing employment. Banking activity expanded moderately from year-earlier levels. Spending rose somewhat, but at a slower rate than the long-term trend.

Near the end of the year total employment was 3.4 per cent higher than in late 1965. Unemployment was 2.8 per cent of the labor force late in 1966 compared with 3.6 per cent a year earlier.

Payroll employment advanced 5 per cent with most of the gain in manufacturing. Employment in the machinery industry rose by several hundred workers, primarily because of expansion by a firm which produces office machines. Other industries showed smaller increases. Among the nommanufacturing groups employment in trade increased most, but employment in construction was also well above year-earlier levels.

7The SMSA is Greene County, Missouri.

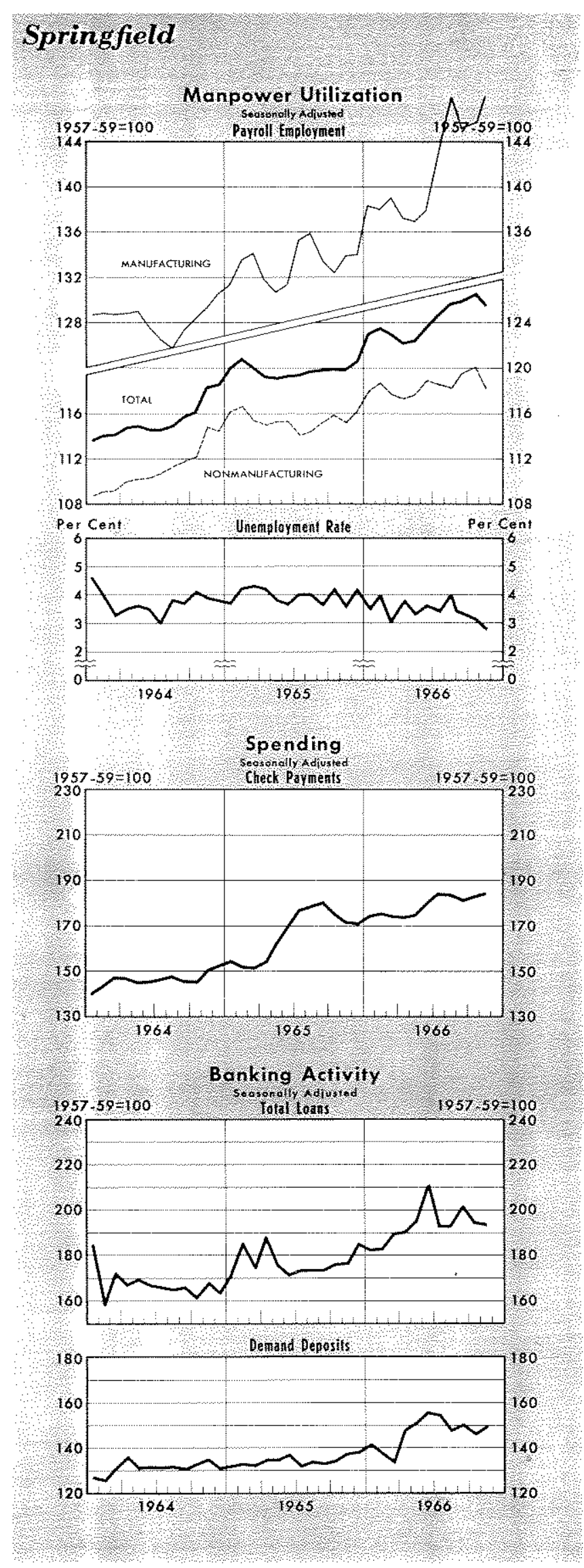

Page 13 

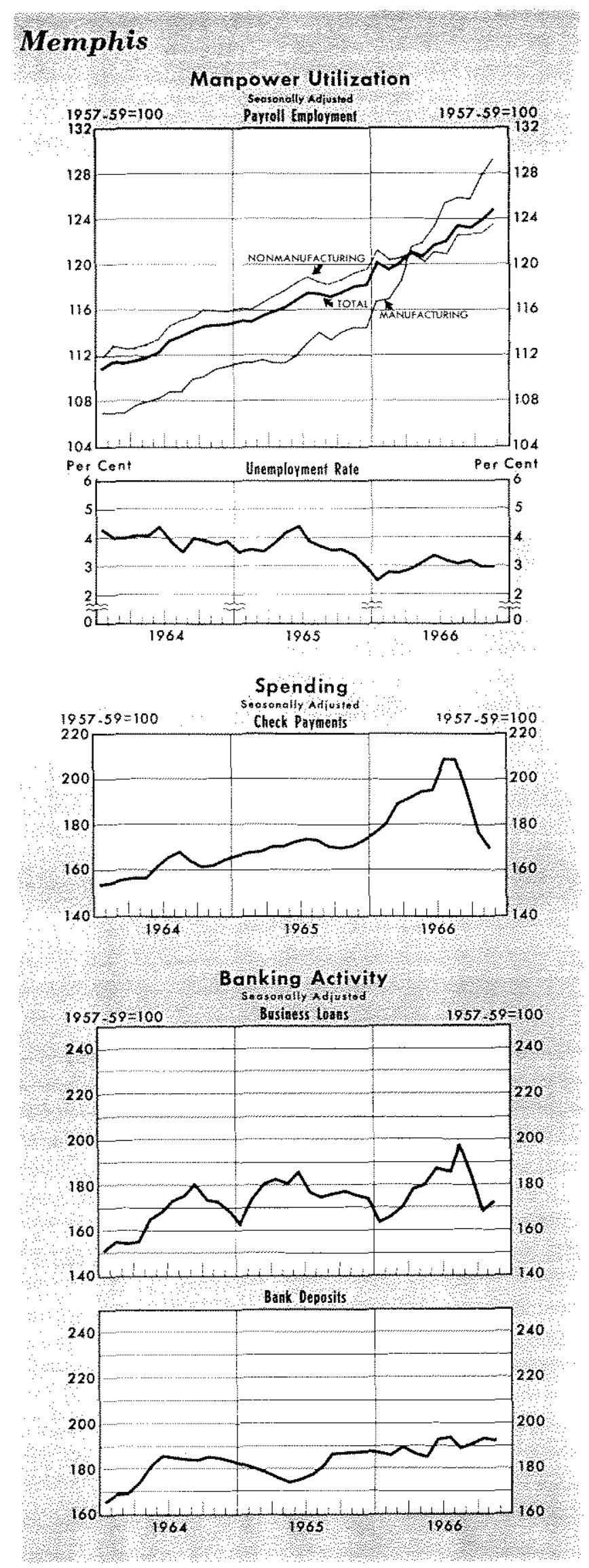

Check payments advanced 5 per cent during the year, substantially below the 8 per cent average anntal increase from 1960 to 1965 . Demand deposits expanded 9 per cent, and total bank loans rose 10 per cent.

\section{Tennessee}

A period of exceptionatly rapid economic expansion in Tennessee which began in mid-1965 continued through 1966. Population growth lagged, but employment and personal income expanded faster than in the nation during the past year.

Population increased 0.9 per cent compared with 1.1 per cent in the nation and a 1,5 per cent average annual rate in Tennessee from 1960 to 1965.

Payroll employment moved strongly upward at a 6 per cent rate compared with a 4.7 per cent increase for the nation. Manufacturing employment advanced 8 per cent. Sharp gains were reported in the electrical machinery, chemical, and apparel industries. Among the nonmanufacturing categories construction, trade, services, and government all showed substantial increases in employment during the year.

Tennessee's 9 per cent gain in personal income exceeded the national rate of growth. Per capita personal income rose from $\$ 2,013$ in 1965 to $\$ 2,172$ in 1966 , an 8 per cent increase.

\section{Memphis ${ }^{8}$}

The Memphis economy displayed widely varying trends in 1966. Employment grow th accelerated sharply, but spending and banking activity rose at belowaverage rates.

Employment in Memphis rose at a faster pace than in the nation. Total employment was 3.6 per cent above year-earlier levels. Payroll employment rose 6 per cent compared with a 4.7 per cent national rate. Much of the area's gain was attributable to a large increase in manufacturing employment. A new plant which produces television sets was opened in mid-1966 and initially employed about 1,000 workers. The work force at the plant is expected to increase to about 2,400 by mid-1967. In addition, several other industries showed employment increases last year. In the nonmanufacturing sector trade, services, and government each had employment increases of more than 1,000 workers. Unemployment was near the 3 per cent level throughout the 12-month period ending in November 1966, well below the rate for most of the previous 12 months.

\footnotetext{
8 The SMSA consists of Shelby County, Tennessee and Crittenden County, Arkansas.
} 
Spending, as measured by check payments, rose rapidly in early 1966 but dropped sharply after midyear. The net gain for the 12 months was 1.6 per cent, substantially below the 9 per cent trend rate for the area.

Banking activity, after rising rapidly during most of the period from 1960 to 1964, slowed considerably during the last two years. Deposits in 1966 moved up
2.9 per cent, well below the 11 per cent annual increase from 1960 to 1965 . This low rate of deposit in. crease probably reflects the 4 per cent limit on interest rates that can be paid on time and savings deposits by Tennessee banks. Business loans rose rapidly during the first seven months of 1966 but declined sharply after August. Near the end of the year these loans were 3.5 per cent below year-earlier levels.

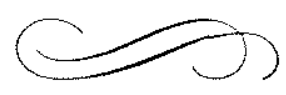

\footnotetext{
BulK MAILINGS of this bank's REVIEW for classroom use will be made montbly during the scbool year to teachers requesting this service. Requests should be directed to: Research Department. Federal Reserve Bank of St. Louis, P. O. Box 442, St. Louis, Missouri 63166.
} 